Article

\title{
Interactive Effects of Stock Type and Forest Vegetation Management Treatments on Douglas-Fir Seedling Growth and Survival-Ten-Year Results
}

\author{
Maxwell G. Wightman ${ }^{1, *}$, Carlos A. Gonzalez-Benecke ${ }^{1}$ (1) and Eric J. Dinger ${ }^{2}$ \\ 1 Department of Forest Engineering, Resources and Management, Oregon State University, \\ Corvallis, OR 97331, USA; carlos.gonzalez@oregonstate.edu \\ 2 Roseburg Resources Company, PO Box 1088, Roseburg, OR 97470, USA; EricD@rfpco.com \\ * Correspondence: maxwell.wightman@oregonstate.edu; Tel.: +1-541-737-4727
}

Received: 9 October 2019; Accepted: 7 November 2019; Published: 8 November 2019

check for updates

\begin{abstract}
In the Pacific Northwest, the use of forest vegetation management (FVM) and seedling stock type selection are important tools to ensure seedling establishment according to organizational objectives and state laws. Individually, these two reforestation decisions have been shown to increase growth and survival of Douglas-fir seedlings, however, the interaction between seedling stock type and level of vegetation control represents economic and ecologic tradeoffs that are less well understood. This study was designed to test the combined effects of three FVM regimes and three containerized stock types, one of which was experimental at the time, on Douglas-fir growth during the initial ten years of establishment on a site near Belfair, Washington (USA). When compared to the no-action control, FVM treatments reduced competitive plant cover below $20 \%$ during the year of application, and differences in vegetation cover persisted through the fifth growing season. Vegetation species diversity recovered quickly after FVM and there were no differences among the treatments by the third growing season. After ten growing seasons, trees in plots treated with FVM were $1.1 \mathrm{~m}$ taller with a mean diameter at breast height (DBH) $2.2 \mathrm{~cm}$ larger than those in the no-action control. Larger seedlings at the time of planting (styro-60) were $0.6 \mathrm{~m}$ taller with a mean DBH $1.1 \mathrm{~cm}$ larger than smaller seedlings (styro- 8 and styro-15). The only significant stock type by FVM interaction in the experiment occurred with the survival of styro-60 seedlings growing in the no action control which had lower survival than all other treatment combinations ( $67 \%$ vs $91 \%)$. The long-term competitive impact of shrub cover was demonstrated by a strong non-linear relationship. Increasing cumulative shrub cover from $10 \%$ to $30 \%$ during the first two years of establishment reduced stand volume at year 10 by $79 \%$.
\end{abstract}

Keywords: Pseudotsuga menziesii; stock size; vegetation control; reforestation; intensive silviculture; available soil water; shrub competition; target plant concept

\section{Introduction}

Understanding the synergies of silvicultural practices is important, as decisions made during the early years of stand establishment can have long-term consequences on stand development. The use of intensive silviculture has been shown to increase the productivity of plantation forests across the world [1-4]. Intensive silvicultural systems commonly include several practices including the use of genetically improved artificial regeneration, mechanical soil preparation, forest vegetation management, fertilizer application, and density management $[5,6]$. Research has shown the benefits of each of these practices on increasing forest growth, however the interactive effects of these practices is less well known. 
In the Unites States Pacific Northwest (PNW), chemical forest vegetation management treatments (FVM) and seedling stock type selection are important tools used by forest managers to establish Douglas-fir (Pseudotsuga menziesii (Mirbel) Franco) plantations in compliance with organizational objectives and state laws. Competition between the plant community and newly planted conifer seedlings is often intense, especially during the dry summer months typical of the region $[7,8]$. The prolonged summer drought period creates intense competition for available soil water, which has been shown to be an important factor affecting the early survival and growth of Douglas-fir seedlings $[7,8]$. The application of FVM treatments creates a temporal reduction in competing vegetation cover, allowing seedlings to better capture available soil water and other vital resources such as nutrients and light $[8,9]$.

Studies have demonstrated that Douglas-fir seedlings respond positively to FVM treatments [3,7,10-13], however the long-term effects of stock type and stock type by FVM interactions on Douglas-fir establishment and growth are not as prevalent in the literature [14]. Van der Driessche (1992) [15] assessed the performance of six different Douglas-fir stock types on a site in South Vancouver Island and found no differences in tree size after six growing seasons despite larger initial differences. In contrast to Van der Driessche (1992) [15], others have reported that larger Douglas-fir planting stock outperformed smaller planting stock $[16,17]$. The different results presented in these studies point to the need for further research that investigates how stock type and silvicultural treatments interact to influence reforestation success.

The Target Plant Concept (TPC) provides a framework for nursery and forest managers to integrate and improve the link between nursery practices and seedling performance in the field [18]. One of the central components of the TPC is the concept of "fitness for purpose" which suggests that seedling quality should be assessed by outplanting performance rather than nursery performance. Applying this concept to better ensure successful reforestation requires detailed information on the performance of various stock types under different silvicultural regimes at the outplanting site. Field performance under a range of operational conditions can also be utilized to direct financial investments, especially when unique stock types are a consideration.

The Vegetation Management Research Cooperative (VMRC) at Oregon State University installed the Combining Weed Control study in 2009 to investigate how interactions among three FVM treatment regimes and three containerized stock types impact the long-term survival and growth of Douglas-fir seedlings on a site near Belfair, WA (USA). The specific objectives of the study were: (1) assess the impact of FVM regime on vegetation community dynamics, (2) assess the impact of FVM regime on available soil water, and (3) determine the effect of FVM regime, stock type, and the interaction of these factors on Douglas-fir seedling morphology, growth, and survival.

\section{Materials and Methods}

\subsection{Study Design}

The VMRC Combining Weed Control study was established in 2008 on lands managed by Olympic Resources Management near Belfair, WA. The Kitsap peninsula site has shallow glaciated soils characterized as very gravelly sandy loam, a mean annual temperature of $11.1^{\circ} \mathrm{C}$, and mean annual rainfall of $1433 \mathrm{~mm}$. Neighboring mature stands bordering the study site are comprised primarily of Douglas-fir mixed with a small portion of western redcedar (Thuja plicata Donn ex D. Don), western hemlock (Tsuga heterophylla (Raf.) Sarg.), and western white pine (Pinus monticola Douglas ex D. Don). The site was clear-cut using a machine harvester during the winter and early spring of 2007-2008.

The study utilized a factorial design with three levels of FVM regime and three levels of containerized stock type for a total of nine unique treatments. The FVM regimes included: a no-action control (OOO), a fall site preparation with a spring release during the first growing season (FTO), and a fall site preparation with a spring release during both the first and second growing seasons (FTT). The fall site preparation treatment was applied on 11th September, 2008, and included a broadcast 
application of $3.51 \mathrm{ha}^{-1}$ glyphosate and $1.81 \mathrm{ha}^{-1}$ imazapyr. The spring release treatments were designed to reduce competitive plant cover below a $20 \%$ threshold throughout the application year. The first growing season spring release consisted of a broadcast application of $0.441 \mathrm{ha}^{-1}$ clopyralid in April 2009 and a direct foliar application of $2 \%$ glyphosate in June 2009. Spring weather conditions in 2010 as well as logistical constraints made it impossible for the second-year broadcast spring release treatment to be applied. However, a direct foliar application of $2 \%$ glyphosate was applied to the FTT plots in June and was sufficient to meet the $<20 \%$ competition cover goal of the study.

The containerized stock types tested include styro-8 (S8), styro-15 (S15), and styro-60 (S60). Seedlings for each stock type were produced using styroblocks ${ }^{\mathrm{TM}}$ (Beaver Plastics, Ltd., Alberta, Canada) with cavity volumes of 130, 250, and 1,000 $\mathrm{mL}$ for the S8, S15, and S60 stock types, respectively. For more detailed information on styroblock dimensions, see Wightman et al. (2018) [14]. Production of the S60 stock type required two years and may occur on a limited basis in forest nurseries. The S60 stock type was produced by growing a cohort of S8 seedlings during 2007. These seedlings were then repotted into styro-60 containers and grown for another season (2008). To be clear, the S60 seedlings were two years old at the time of planting, whereas the S8 and S15 seedlings were one year old. The cost of the $S 8, S 15$, and $S 60$ seedlings was $\$ 0.25, \$ 0.35$, and $\$ 1.25$ per seedling, respectively. A list of the treatments included in this analysis is provided in Table 1.

Table 1. Description of vegetation control and stock type treatments. Vegetation management regimes include a fall site preparation, a spring release in year one and a spring release in year two. Stock sizes include styro-8 (S8), styro-15 (S15), and styro-60 (S60).

\begin{tabular}{cccc}
\hline Treatment & & Vegetation Control & Stock Size \\
\hline 1 & OOO & No-action Control & S8 \\
2 & FTO & Fall Site Preparation + Spring Release in Year 1 & S8 \\
3 & FTT & Fall Site Preparation + Spring Release in Years 1 and 2 & S8 \\
4 & OOO & No-action Control & S15 \\
5 & FTO & Fall Site Preparation + Spring Release in Year 1 & S15 \\
6 & FTT & Fall Site Preparation + Spring Release in Years 1 and 2 & S15 \\
7 & OOO & No-action Control & S60 \\
8 & FTO & Fall Site Preparation + Spring Release in Year 1 & S60 \\
9 & FTT & Fall Site Preparation + Spring Release in Years 1 and 2 & S60 \\
\hline
\end{tabular}

Seedlings were planted on January 13 and 14, 2009, at a spacing of $3.05 \times 3.05 \mathrm{~m}\left(1076\right.$ trees ha $\left.^{-1}\right)$ and were protected from ungulate browse with $15 \mathrm{~cm}$ diameter Vexar ${ }^{\circledR}$ tubing. Treatment plots were $30 \times 30 \mathrm{~m}$ allowing for the internal measurement plot of 8 rows of 8 trees to be surrounded by a one tree buffer row on all sides. Each treatment was replicated four times using a randomized complete block design for a total of 27 plots.

\subsection{Tree and Vegetation Measurements}

Seedling height, ground-line diameter and, when achieved, DBH (diameter at breast height, $1.37 \mathrm{~m}$ ) was measured during the dormant season of years 1-5, 8, and 10. Ground cover vegetation assessments were conducted during July of growing seasons 1-5 and 10 on five $1 \mathrm{~m}$ radius subplots within each experimental unit. Subplots were randomly located equidistant between measurement trees. A vegetation survey was conducted in September 2008 prior to the application of the fall site preparation treatment to assess pre-treatment site conditions. All vegetation assessments included visual estimates of plant cover percentage by species. Each species found was assigned one of the following growth habits: forb, fern, graminoid, shrub, vine/shrub (Rubus species) or tree. Any vegetation over $2 \mathrm{~m}$ in height and all crop trees were excluded from surveys. Total cover was calculated as the summation of all species-level cover percentages on a given subplot and therefore, total cover can exceed 100 percent.

Initial pre-planting measurements were conducted on a subset of 40 seedlings of each stock type. Two or three unopened bags of seedlings were randomly selected from those at the planting site and 
brought back to OSU laboratory facilities for morphologic assessments including seedling height, root-collar diameter, shoot volume (shoots + needles), and root volume. Seedlings were removed from the bags and the roots gently washed to remove potting media prior to morphologic assessments. Shoot and root volume measurements were made using the water displacement method and shoot volume was measured with live needles still attached, therefore reflecting the volume of all aboveground tissues [19].

\subsection{Soil Moisture Measurements}

Soil volumetric water content was measured using vertically oriented, 20-cm-long capacitive soil moisture probes (EC-20, Decagon Devices, Pullman, WA, USA) on 2 random points inside three replicates of each treatment regime. Soil moisture estimates using the capacitive probe were calibrated for the study site using a process specific to the glaciated soils on the site. A large quantity of soil from the A horizon in several blocks was sieved through a $2 \mathrm{~mm}$ screen and taken back to laboratory facilities at Oregon State University. A portion of this sieved soil was used for sensor calibration while the remainder was reserved for on-site sensor deployment. Plastic window screen and a hose clamp were attached to one end of a $10 \mathrm{~cm}$ diameter $\times 45 \mathrm{~cm}$ long polyvinyl chloride tube. Alternating between sieved soil and water, EC-20 sensors were centrally encased in the PVC tubes. Soil wetting continued until field capacity was reached (i.e., the amount of water added to the top of the PVC pipe was within 10 grams of the water collected at the bottom). Sensors were then programmed to take twice daily measurements for a period of 14 weeks. Once per week, each tube was weighed. When soil moisture percentages were no longer declining, the length of the sieved soil was measured, removed, dried in a laboratory oven for 72 hours at $68{ }^{\circ} \mathrm{C}$, and weighed. After subtracting the weight of the sensor, screen, hose clamp, and PVC tube, these data permitted the calculation of soil moisture percentage at each date the entire core had been weighed. This dataset served as the basis for the development of a calibration equation using regression analysis to compare the EC-20 reading with the actual moisture content on a given date.

The same EC-20 sensors were then taken to the study site for deployment. An $8 \mathrm{~cm}$ soil auger was used to remove site soils and minimize disturbance to neighboring plant roots, rocks, and soil. The EC-20 probes were installed centrally using a similar process of adding sieved soil and water in an alternating fashion. Fractional available soil water (ASW) was calculated for each plot and day by analyzing the limits of wetting and drying of the soil through the entire study period. Drained upper limits (DUL) and lower limits of water extraction (LL) were determined for each plot and ASW was calculated using the formula proposed by Ritchie (1981) [20]:

$$
\mathrm{ASW}=1-(\mathrm{DUL}-\mathrm{WC}) /(\mathrm{DUL}-\mathrm{LL})
$$

where ASW is available soil water, DUL is drained upper limit, WC is volumetric water content, and LL is the lower limit of water extraction. An automatic weather station (HOBO H21-002; Onset Computer Corporation, Massachusetts, USA) was used to collect weather data, including air temperature, relative humidity, wind speed, solar radiation, and rainfall.

\subsection{Statistical Analysis}

Stem volume was calculated following Maguire et al. (2009) [13], where the volume of the section below $1.37 \mathrm{~m}$ was calculated as a cylinder with basal diameter equal to DBH and the volume of the top section above $1.37 \mathrm{~m}$ was calculated as a cone with basal diameter equal to DBH. After summing the stem volume of all living seedlings, volume per hectare $\left(\mathrm{m}^{3} \mathrm{ha}^{-1}\right)$ was determined for each measurement plot using the plot expansion factor. Analysis of variance, including Tukey adjustments, was performed using the mixed procedure in SAS 9.4 (SAS Institute Inc., Cary, NC, USA) 
to test fixed treatment effects on tree morphology and vegetation community dynamics while including the random effect of block. The linear model for the analysis was:

$$
Y_{i j k}=\mu+V_{i}+S_{j}+V_{i j}+B_{k}+\varepsilon_{i j k}
$$

where $\mathrm{Y}_{\mathrm{ijk}}$ is the parameter value of the plot with the ith level of FVM regime (V), the jth level of stock type (S), in the kth block (B) and $\mu$ is the population mean and $\varepsilon_{\mathrm{ijk}}$ is the error term $\sim \mathrm{NID}(0, \sigma 2 \varepsilon)$ (NID, normally and independently distributed).

Analysis of co-variance was used to test the effects of treatments on seedling morphology using initial size as the covariate. Linear regression analysis was used to correlate seedling size and shoot and root volume. Non-linear regression analysis was used to correlate vegetation cover and stand volume production. Allometric equations were developed to calculate seedling shoot volume and root volume from seedling diameter and height. Several models were tested for this relationship and the model selected was:

$$
\ln \left(V_{i}\right)=a+b \cdot \ln \left(D^{2} H\right)
$$

where $V_{i}$ is volume (root or shoot, $\mathrm{cm}^{3}$ ) $a$ and $b$ are curve fit parameter estimates, $D$ represents seedling root collar diameter $(\mathrm{cm})$, and $H$ represents seedling height $(\mathrm{cm})$. These equations were then applied to the initial inventory data to calculate plot-level averages for seedling shoot volume and root volume, and this dataset was used to correlate seedling survival rate with initial seedling size. Repeated measures analysis was used to analyze time series of ASW. Several covariance structure models were used for the time series and the heterogeneous first-order autoregressive model was selected as it showed the lowest Schwartz's Bayesian information criterion [21].

\section{Results}

\subsection{Plant Community Dynamics}

Prior to study installation (year $=-1$ ) there were no differences in vegetation cover among the FVM regimes ( $p=0.984$ ), averaging 39\% cover, and the most common species at the study site were Gaultheria shallon (salal), Rubus ursinus (trailing blackberry), Vaccinium ovatum (evergreen huckleberry), Pteridium aquilinum (bracken fern), Hypochaeris radicata (false dandelion), and Senecio sylvaticus (woodland ragwort). After the initiation of the FVM regimes, stock type did not affect total vegetation cover in any year $(p>0.484)$, so cover percentages were averaged by FVM regime across all stock types in each block for analysis.

The herbicide treatments applied in this study reduced vegetation cover during the year of application and continued to affect the composition and cover of vegetation through the fifth growing season (Figures 1 and 2). The herbicide treatments applied in the first year (FTO and FTT) significantly reduced vegetation cover and species per plot during the first growing season when compared to the no-action control (54\% vs 16\%; $p<0.001)$. At this time, the cover of OOO plots was dominated by Rubus ursinus (trailing blackberry), Gaultheria shallon (salal), Vaccinium ovatum (evergreen huckleberry), and Pteridium aquilinum (bracken fern). When analyzed by growth habit, the year 1 herbicide treatment significantly reduced the cover of forbs, ferns, shrubs, and vine/shrubs when compared to the no-action control during the first growing season (Figure $2 ; p<0.001$ ). The cover of graminoids and trees was minimal in all plots during the first growing season and the species per plot of the no-action control was, on average, eight species greater than the FTO and FTT regimes $(p<0.001$; Figure 2$)$. 


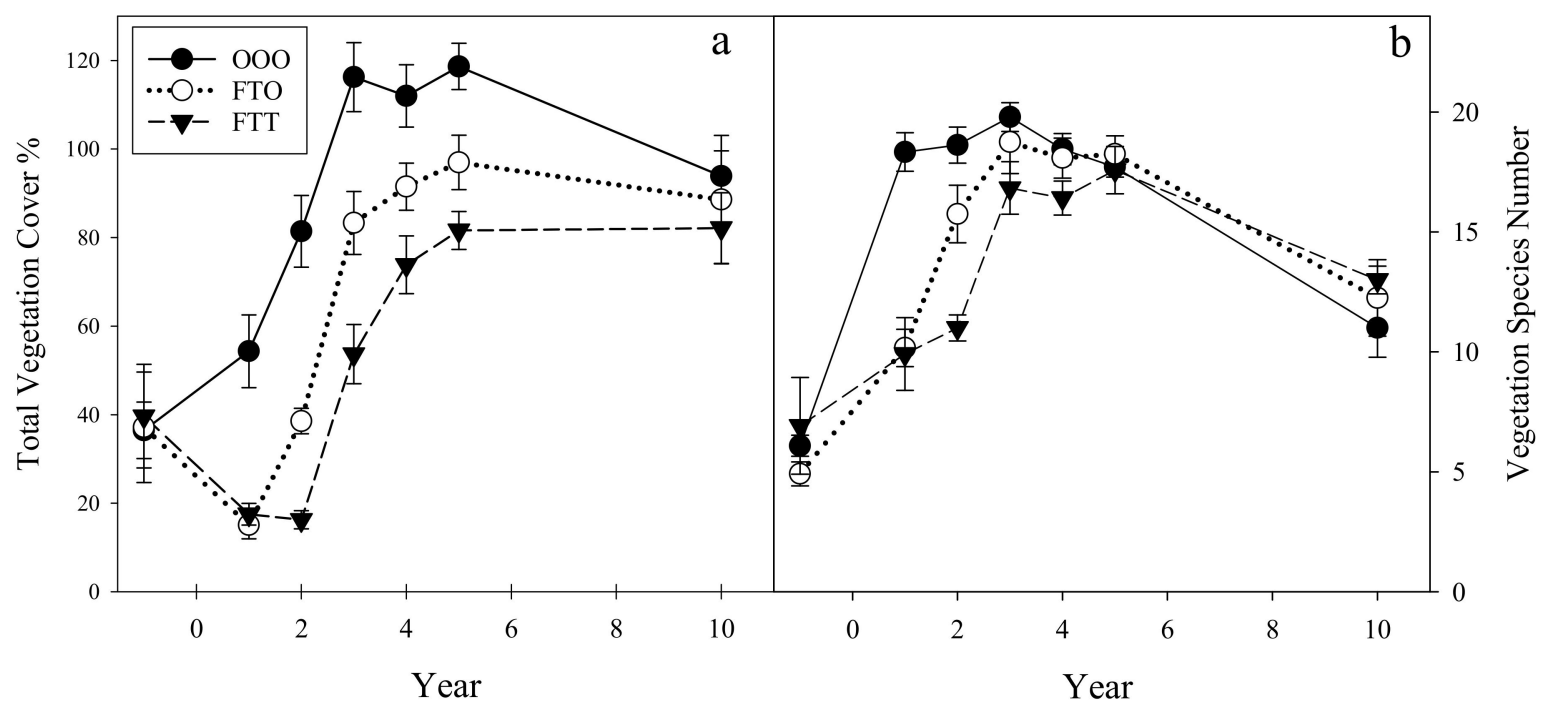

Figure 1. Forest vegetation management treatment regime effect on: (a) development of summed vegetation cover over time, and (b) changes in the average number of species per plot over time. Treatment descriptions are provided in Table 1.

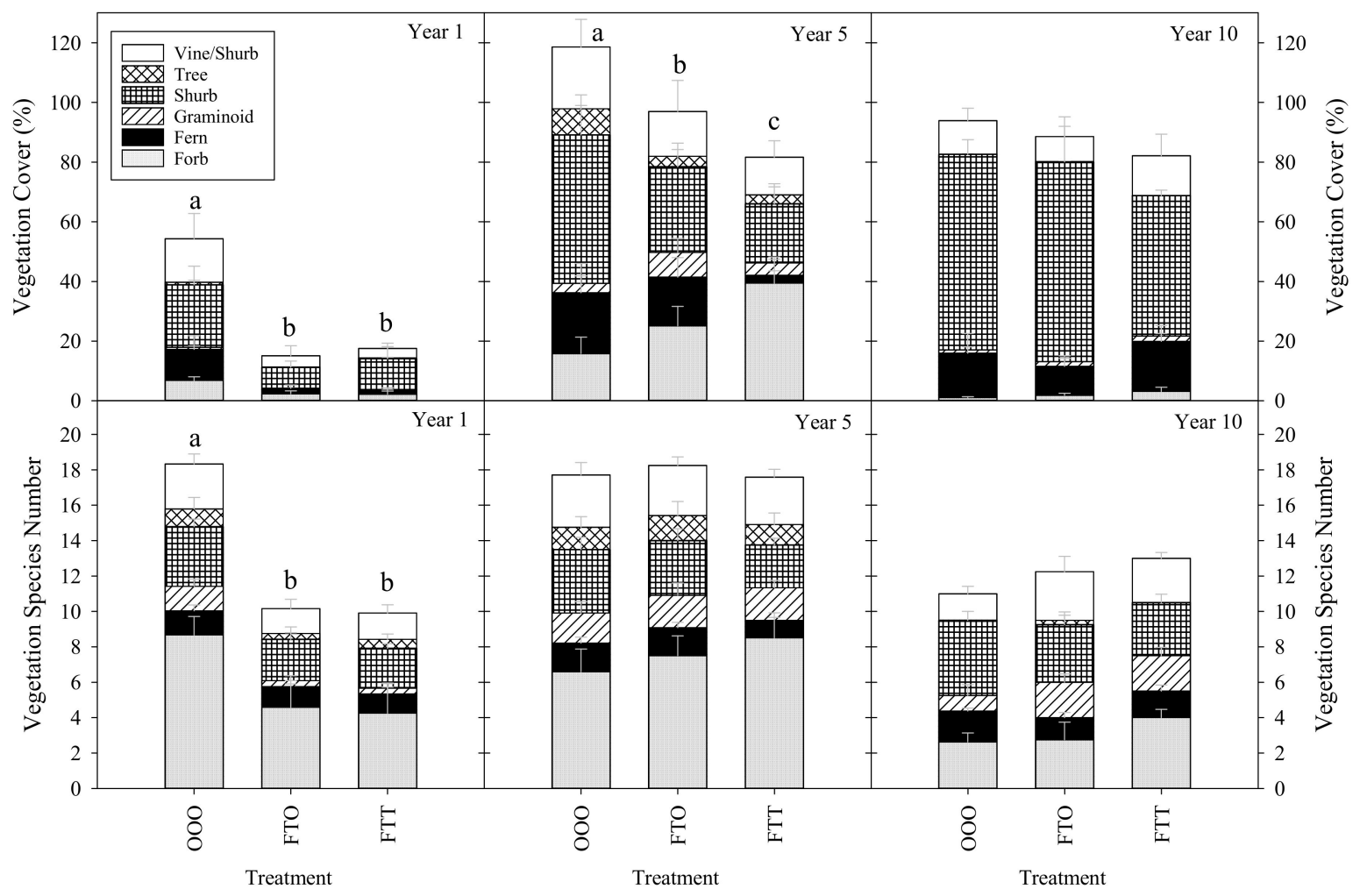

Figure 2. Vegetation community composition during years 1, 5, and 10 (left to right). Summed vegetation cover (top panel) and average species number per plot (bottom panel) are presented by growth habit for each vegetation management regime. When significant differences were found, letters over each bar represent significant differences for total cover (top) or species number (bottom) at a significance level of $\alpha=0.05$. Treatment descriptions are provided in Table 1.

During the second year, the early summer glyphosate treatment applied to the FTT plots reduced vegetation cover when compared to the FTO regime ( $15 \%$ vs $39 \%$ cover; $p=0.033$ ). The no-action control had greater vegetation cover than both the FTO and FTT regimes during the second year and averaged $81 \%$ cover $(p<0.001)$. The higher vegetation cover in the control was, in part, due to 
this treatment having greater shrub cover than the other regimes $(27 \%$ vs $8 \% ; p<0.003)$. After the treatment regimes were completed, vegetation cover began to increase in all FVM regimes through year 5 (Figure 1a). Their relative differences, however, were maintained with the OOO plots having the highest vegetation cover, FTT the lowest, and FTO between these two extremes. There were no differences among the regimes in the average number of species per plot during years 3-5, even when analyzed by growth habit. During these years, there were, on average, 18 species growing in each plot $(p=0.797)$.

In year 5 , vegetation cover in the OOO plots $(118 \%)$ was larger than the FTO $(p=0.007)$ and the cover in the FTO plots $(97 \%)$ was larger than the FTT $(82 \%, p=0.033)$. Gaultheria shallon (salal), Rubus ursinus (trailing blackberry), Pteridium aquilinum (bracken fern), Hypochaeris radicata (false dandelion), and Vaccinium ovatum (evergreen huckleberry) were the most common species at year 5 , accounting for $80 \%$ of all vegetation cover across all stock types and vegetation management regimes.

The persistent effect of the treatment regimes on vegetation cover during the first five years of the study was largely due to differences in the cover of shrubs. In year 5 , the shrub cover of the OOO regime $(50 \%)$ was greater than the FTO $(p=0.005)$ and the shrub cover of the FTO regime $(28 \%)$ was greater than the FTT regime $(20 \%)$ although this difference was not significant $(p=0.145)$. Salal (Gaultheria shallon) was the dominant shrub in all plots and the cover of this species was significantly reduced but not eliminated by the herbicide treatments $(p=0.042)$. Salal cover averaged $36 \%, 25 \%$, and $17 \%$ cover at year 5 for the OOO, FTO, and FTT regimes, respectively. The FTT regime had higher forb and lower fern cover than the no-action control at year $5(p<0.041)$, however the cover of these lifeforms did not differ between the FTO and OOO regimes ( $p>0.167$; Figure 2).

After 10 growing seasons, there were no differences in total vegetation cover $(p=0.476)$ or species per plot $(p=0.422)$ among the FVM regimes, even when analyzed by growth habit (cover $p>0.1801$; species number $p>0.075$ ). Plots averaged $90 \%$ cover and 12 species at year 10 . Shrubs were the dominate growth habit on the site, averaging $61 \%$ cover, while the cover of forbs had declined below $3 \%$. Gaultheria shallon (salal), Vaccinium ovatum (evergreen huckleberry), Rubus ursinus (trailing blackberry), Pteridium aquilinum (bracken fern), and Polystichum munitum (sword fern) were the most abundant plant species in year 10.

\subsection{Soil Moisture}

The Mediterranean climate of the Pacific Northwest is known for having wet winters and dry summer months, a fact illustrated by the weather station and soil moisture data. Between June 15 and September 15, total rainfall was about 53, 42, and $50 \mathrm{~mm}$, for years 2009, 2010, and 2011, respectively (Figure 3). Differences in vegetation cover among the FVM regimes during the first two growing seasons of the study impacted soil moisture dynamics (Figure 3). During the first growing season (2009), the FTO and FTT plots had higher ASW than the OOO plots between May 27 and October 14 $(p<0.048)$, even though there was an increase is ASW in all plots due to $47 \mathrm{~mm}$ of rainfall during September and early October (Figure 3). During the second growing season (2010), the FTT plots showed larger ASW than the OOO and FTO plots between July 1 and September $16(p<0.045)$. During this year, the FTO plots did not receive a vegetation control treatment and showed similar ASW to the OOO plots $(p>0.16)$. During the third growing season (2011), the ASW of all plots was similar $(p>0.34)$ except for the FTT plots having higher ASW than the OOO and FTO plots between July 22 and August $4(p<0.029)$, after a large recharge in ASW due to $18.6 \mathrm{~mm}$ of rainfall during mid-July (Figure 3). 


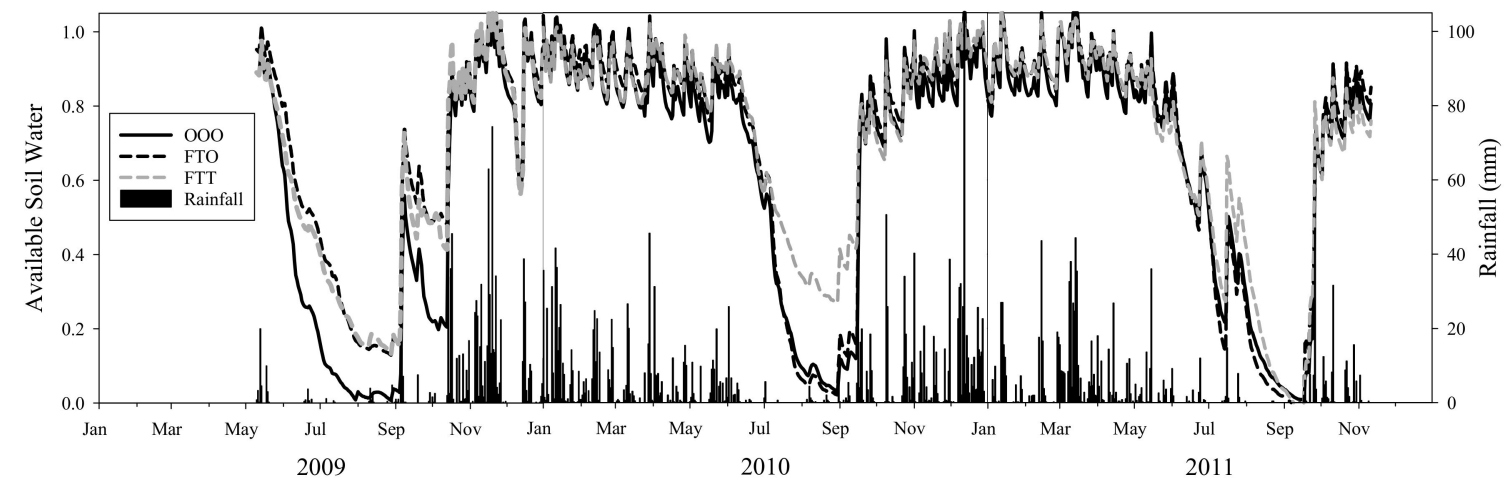

Figure 3. Effect of vegetation management regime on available soil water during the first three growing seasons (5 September 2009-11 November 2011). Daily precipitation is depicted by the vertical bars. Treatment descriptions are provided in Table 1.

\subsection{Seedlings}

Initial pre-planting measurements on seedling morphology indicated significant differences in seedling height $(p<0.001)$, root-collar-diameter $(p<0.001)$ and stem volume $(p<0.001)$. Seedling size at the time of planting increased with each incremental expansion in cavity volume (Table 2$)$. The root volume of the S8 seedlings did not significantly differ from the S15 seedlings $(p=0.430)$, however, the S60 stock type had significantly larger root volume than the others $(p<0.001)$. The S15 seedlings had a moderately higher H:D ratio when compared to the other stock types $(p<0.081)$. A similar pattern was observed for shoot to root volume ratio.

Table 2. Initial seedling height $(\mathrm{H})$, root-collar-diameter (RCD), height to root collar diameter ratio (H:D), shoot volume, root volume and shoot to root volume ratio (S:R) of styro-8 (S8), styro-15 (S15), and styro-60 (S60) Douglas-fir seedlings. Values after \pm represent standard error. Within a column, variables that share a letter are not significantly different at $\alpha=0.05(n=40)$.

\begin{tabular}{ccccccc}
\hline Stock & $\mathbf{H}(\mathbf{c m})$ & $\mathbf{R C D}(\mathbf{m m})$ & $\begin{array}{c}\mathbf{H}: \mathbf{D}(\mathbf{c m} \\
\left.\mathbf{c m}^{-\mathbf{1}}\right)\end{array}$ & $\begin{array}{c}\text { Shoot } \\
\text { Volume } \\
\mathbf{( \mathbf { c m } ^ { 3 } )}\end{array}$ & $\begin{array}{c}\text { Root } \\
\text { Volume } \\
\left.\mathbf{( c m}^{\mathbf{3}}\right)\end{array}$ & S:R \\
\hline S8 & $24.0 \pm 0.5 \mathrm{a}$ & $3.3 \pm 0.1 \mathrm{a}$ & $74.7 \pm 2.0 \mathrm{a}$ & $6.5 \pm 0.3 \mathrm{a}$ & $6.1 \pm 0.3 \mathrm{a}$ & $1.11 \pm 0.05 \mathrm{~b}$ \\
$\mathrm{~S} 15$ & $29.9 \pm 0.6 \mathrm{~b}$ & $3.7 \pm 0.1 \mathrm{~b}$ & $82.7 \pm 2.1 \mathrm{~b}$ & $12.0 \pm 0.6 \mathrm{~b}$ & $9.6 \pm 0.5 \mathrm{a}$ & $1.32 \pm 0.06 \mathrm{a}$ \\
$\mathrm{S} 60$ & $68.0 \pm 1.2 \mathrm{c}$ & $8.9 \pm 0.1 \mathrm{c}$ & $76.8 \pm 1.7 \mathrm{a}$ & $56.1 \pm 1.8 \mathrm{c}$ & $51.5 \pm 3.4 \mathrm{~b}$ & $1.25 \pm 0.07 \mathrm{ab}$ \\
\hline
\end{tabular}

Allometric equations were created utilizing the pre-planting seedling dataset to calculate shoot volume and root volume as a function of seedling diameter and height, as these measurements are easier to make in a field setting. The resulting equations were:

$$
\begin{gathered}
\ln (\text { shoot volume })=-0.121+1.014 \cdot \ln \left(D^{2} H\right) \\
\ln (\text { root volume })=-0.168+0.977 \cdot \ln \left(D^{2} H\right)
\end{gathered}
$$

where $D$ represents seedling root collar diameter $(\mathrm{cm}), H$ represents seedling height $(\mathrm{cm})$, and shoot volume and root volume are expressed as $\mathrm{cm}^{3}$. The coefficient of determination $\left(R^{2}\right)$ of the shoot and root volume equations were 0.94 and 0.86 , respectively.

Table 3 provides a summary of the year 10 tree measurements and a summary of treatment effects is provided in Table 4. Covariance analysis showed that initial seedling size was not significant for DBH $(p=0.620)$ and height $(p=0.435)$ response at year 10. Initial seedling size was therefore not included in the ANOVA models. Seedling height and DBH were affected by both FVM regime and stock type after ten growing seasons, but the interaction of these two main effects was not significant (Table 4$)$. Mean tree height was significantly affected by both FVM $(p<0.001)$ and stock size $(p=0.004)$ 
such that trees in the FTO and FTT regimes were, on average, $1.1 \mathrm{~m}$ taller than the OOO treatment and the $\mathrm{S} 60$ seedlings had a mean height $0.6 \mathrm{~m}$ greater than the other two stock types (Figure $4 \mathrm{a}, \mathrm{b}$ ). There was a trend for the mean height of FTT plots to be greater than FTO plots $(6.7 \mathrm{~m}$ vs $6.3 \mathrm{~m})$, however this effect was marginally non-significant $(p=0.067)$. Mean height did not differ between the S8 and S15 stock types $(p=0.994)$.

Table 3. Mean height $(\mathrm{m})$, diameter at breast height $(\mathrm{DBH}, \mathrm{cm})$, mean tree volume (Tree Vol, $\left.\mathrm{m}^{3}\right)$, stocking (TPH, trees ha ${ }^{-1}$ ) and stand volume (Stand $\mathrm{Vol}, \mathrm{m}^{3} \mathrm{ha}^{-1}$ ) at year 10 for Douglas-fir seedlings growing under different forest vegetation management (FVM) and stock type treatments. Values after \pm represent standard error. Within a column, values that share a letter are not significantly different at $\alpha=0.05$. Treatment descriptions are provided in Table 1.

\begin{tabular}{ccccccc}
\hline Stock & $\begin{array}{c}\text { FVM } \\
\text { Treatment }\end{array}$ & Height M & DBH cm & Tree Vol d m & TPH Trees ha & Stand Vol $\mathbf{~ m}^{\mathbf{3}} \mathbf{h a}^{\mathbf{- 1}}$ \\
\hline S8 & OOO & $5.0 \pm 0.5 \mathrm{a}$ & $5.5 \pm 0.5 \mathrm{a}$ & $9.4 \pm 2.0 \mathrm{a}$ & $770 \pm 58 \mathrm{ab}$ & $7.5 \pm 1.7 \mathrm{a}$ \\
S8 & FTO & $6.2 \pm 0.5 \mathrm{bc}$ & $7.8 \pm 0.9 \mathrm{~cd}$ & $20.5 \pm 5.3 \mathrm{ab}$ & $837 \pm 48 \mathrm{~b}$ & $17.4 \pm 4.9 \mathrm{abcd}$ \\
S8 & FTT & $6.5 \pm 0.6 \mathrm{bc}$ & $8.7 \pm 1.2 \mathrm{~cd}$ & $25.9 \pm 7.9 \mathrm{~b}$ & $896 \pm 33 \mathrm{~b}$ & $23.0 \pm 6.6 \mathrm{~cd}$ \\
S15 & OOO & $5.1 \pm 0.4 \mathrm{a}$ & $5.9 \pm 0.6 \mathrm{ab}$ & $11.0 \pm 2.5 \mathrm{a}$ & $789 \pm 60 \mathrm{ab}$ & $8.4 \pm 2.1 \mathrm{ab}$ \\
S15 & FTO & $6.2 \pm 0.7 \mathrm{bc}$ & $8.0 \pm 1.0 \mathrm{~cd}$ & $21.7 \pm 7.6 \mathrm{ab}$ & $883 \pm 37 \mathrm{~b}$ & $18.6 \pm 5.5 \mathrm{abcd}$ \\
S15 & FTT & $6.5 \pm 0.5 \mathrm{bc}$ & $8.7 \pm 1.0 \mathrm{~cd}$ & $25.5 \pm 6.7 \mathrm{~b}$ & $841 \pm 46 \mathrm{~b}$ & $21.3 \pm 5.5 \mathrm{~cd}$ \\
S60 & OOO & $6.0 \pm 0.7 \mathrm{ab}$ & $7.3 \pm 0.9 \mathrm{bc}$ & $18.0 \pm 5.4 \mathrm{ab}$ & $621 \pm 73 \mathrm{a}$ & $11.9 \pm 5.1 \mathrm{abc}$ \\
S60 & FTO & $6.4 \pm 0.7 \mathrm{bc}$ & $8.4 \pm 1.3 \mathrm{~cd}$ & $25.0 \pm 9.3 \mathrm{~b}$ & $837 \pm 52 \mathrm{~b}$ & $20.4 \pm 7.3 \mathrm{bcd}$ \\
S60 & FTT & $7.1 \pm 0.6 \mathrm{c}$ & $9.2 \pm 0.7 \mathrm{~d}$ & $29.3 \pm 5.9 \mathrm{~b}$ & $879 \pm 53 \mathrm{~b}$ & $25.4 \pm 4.4 \mathrm{~cd}$ \\
\hline
\end{tabular}

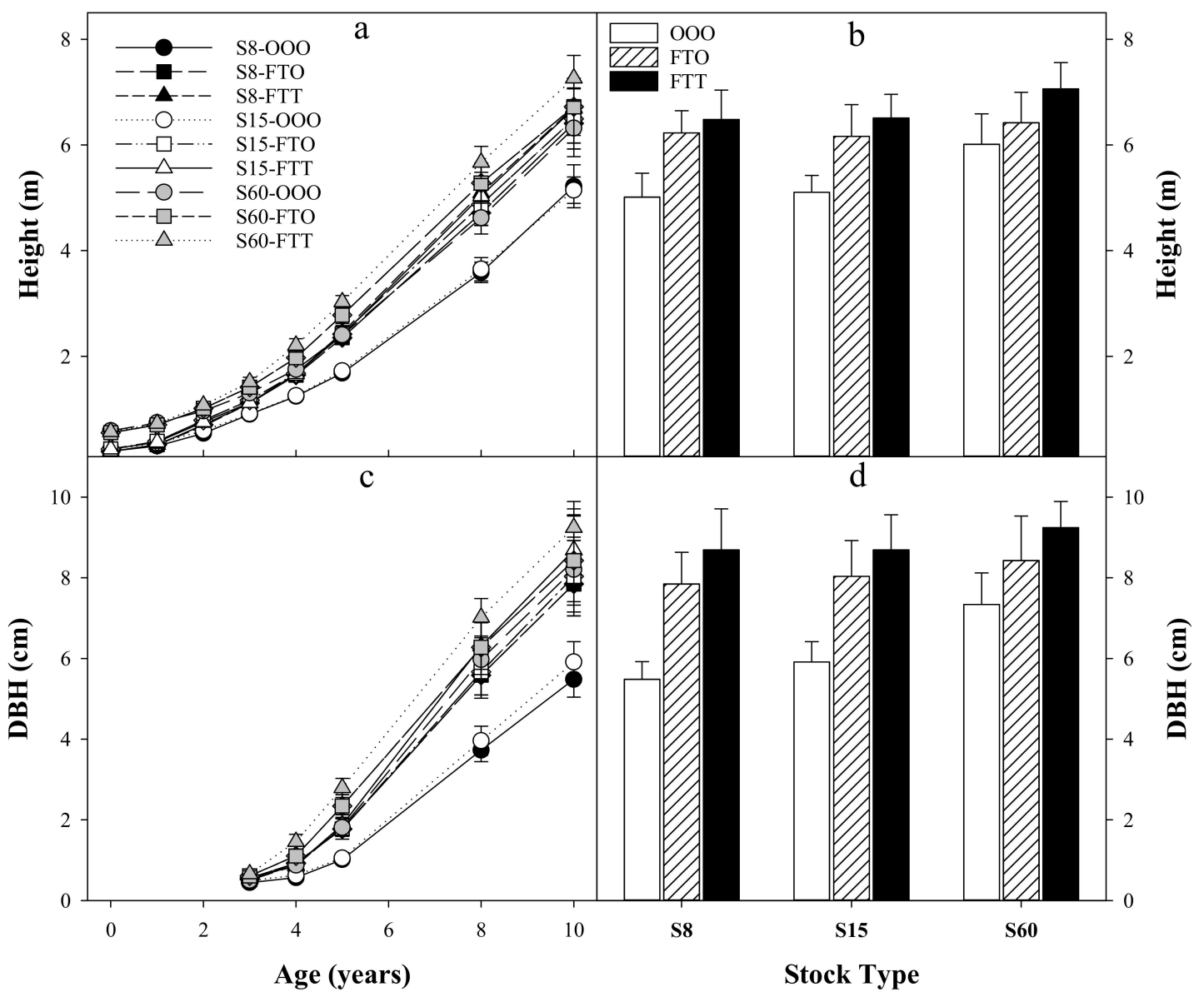

Figure 4. Effect of stock type and vegetation management regime on Douglas-fir: (a) mean height over time, (b) mean height at year 10, (c) mean diameter at breast height (DBH) over time, and (d) mean DBH at year 10. Treatment descriptions are provided in Table 1 and treatment comparisons are provided in Table 3. 
Table 4. Results of ANOVA tests for the effects of vegetation management regimes (FVM) and seedling stock type on Douglas-fir mean height, diameter at breast height (DBH), individual tree volume, trees per hectare (TPH), and stand volume atyear 10. Significant effects are denoted in bold. Treatment descriptions are provided in Table 1.

\begin{tabular}{cccc}
\hline Variable & FVM & Stock Type & Stock Type x FVM \\
\hline Height & $<0.001$ & 0.004 & 0.438 \\
DBH & $<0.001$ & 0.001 & 0.413 \\
Tree Volume & $<0.001$ & 0.051 & 0.889 \\
TPH & $<0.001$ & 0.222 & 0.195 \\
Stand Volume & $<0.001$ & 0.217 & 0.965 \\
\hline
\end{tabular}

When examining the individual treatment combinations, the S8 OOO and S15 OOO treatments were shorter than all other plots where these stock types received more intense vegetation control $(p<0.023 ; 5.1 \mathrm{~m}$ vs $6.3 \mathrm{~m})$. The mean height of the $\mathrm{S} 60 \mathrm{OOO}$ treatment was $0.9 \mathrm{~m}$ taller than the other stock types in the OOO FVM regime, but this effect was marginally non-significant $(p>0.068)$. The height of the S60 FTT treatment, however, was $2.0 \mathrm{~m}$ taller than the S8 OOO and S15 OOO treatments $(p<0.001)$.

Treatment response patterns for DBH were similar to that of height (Figure 4). The FTO and FTT regimes had mean DBHs $2.2 \mathrm{~cm}$ larger than the control $(p<0.001)$ and the S60 stock type had DBHs that were $1.1 \mathrm{~cm}$ larger than the S8 $(p=0.011)$ and S15 stock types $(p=0.048)$. Again, there was a trend for the mean DBH of the FTT regime to be larger than the FTO $(8.9 \mathrm{vs} 8.1 \mathrm{~cm})$, but this effect was marginally non-significant $(p=0.054)$. Similar to height, the $\mathrm{S} 8 \mathrm{OOO}$ and $\mathrm{S} 15 \mathrm{OOO}$ treatments had smaller DBHs than all other plots of these stock types that received at least one spring release $(p<0.035 ; 5.7 \mathrm{~cm}$ vs $8.3 \mathrm{~cm}$ ). The mean DBH of the $\mathrm{S} 60 \mathrm{OOO}$ treatment was $1.9 \mathrm{~cm}$ larger than the S8 OOO treatment $(p=0.048)$. The S60 FTT treatment had a significantly larger mean DBH than all stock types growing under the OOO FVM regime $(p<0.039)$ and averaged $9.2 \mathrm{~cm}$.

There was a significant FVM regime by stock type interaction for seedling survival during the first growing season $(p=0.003)$, such that the survival of the $\mathbf{5 6 0} \mathrm{OOO}$ treatment was less than all other treatments (67\% vs 91\%; $p<0.001$; Figure 5c). The significant Stock Type by FVM regime interaction persisted through year $4(p<0.011)$ but had dissipated by year $5(p=0.067)$ due to the lower survival rate of the S8 OOO and S15 OOO treatments during years $2-5$ (Figure $5 \mathrm{c}$ ). By year 5 , survival was not different among the stock types $(p>0.124)$, but there was a significant effect of FVM regime $(p<0.001)$. Survival in the OOO plots was lower than FTO and FTT plots. Survival of the FTO and FTT treatments did not differ in year 5 ( $p=0.995)$. This trend continued through year 10 when seedling survival averaged 68,79 , and $81 \%$ for the OOO, FTO, and FTT regimes, respectively. While not statistically significant, it is noteworthy that the survival of the $\mathrm{S} 60 \mathrm{OOO}$ treatment was lower than all other treatments throughout the study averaging only $58 \%$ in year 10 .

The lower survival rate of larger seedlings in the OOO treatment during the first growing season was correlated ( $p=0.006 ; R^{2}=0.54$ ) with shoot volume at the time of planting, but this relationship was not observed for seedlings in the FTO or FTT treatments (Figure 6). 


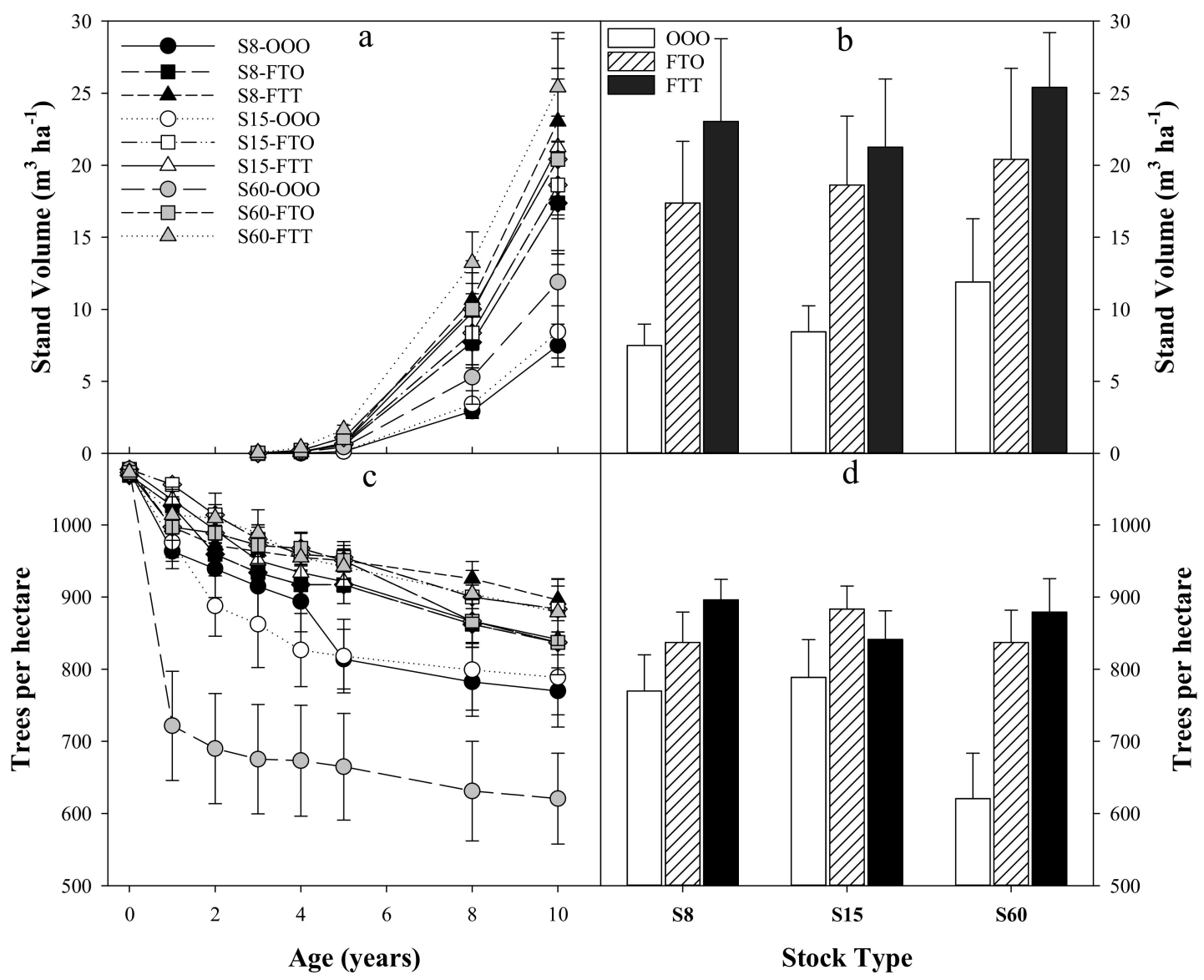

Figure 5. Effect of stock type and vegetation management regime on Douglas-fir: (a) mean stand volume over time, (b) stand volume in year 10, (c) mean trees per hectare over time, and (d) mean trees per hectare in year 10. Treatment descriptions are provided in Table 1 and treatment comparisons are provided in Table 3.

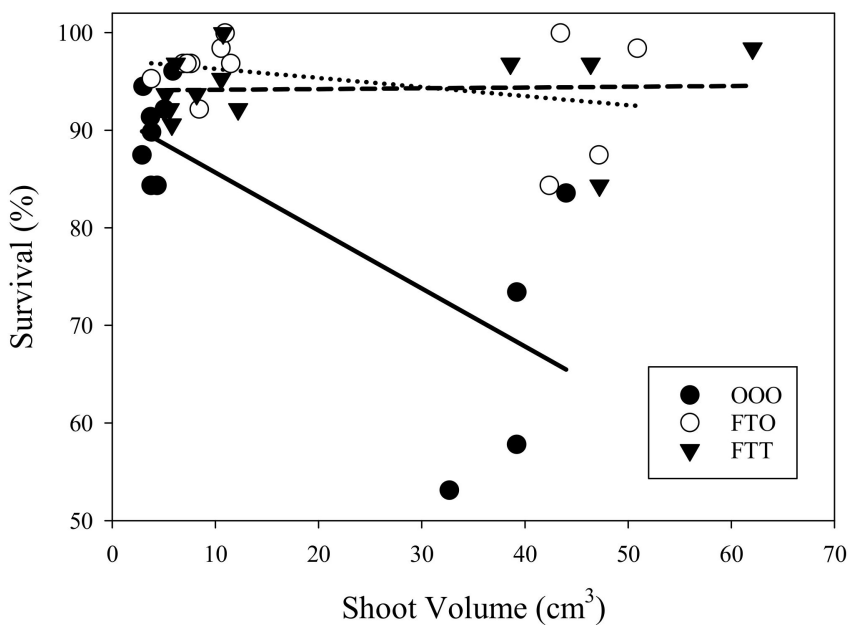

Figure 6. Relationship between seedling shoot volume at the time of planting and survival rate (\%) after the first growing season for Douglas-fir seedlings growing under different forest vegetation management regimes. Lines represent linear model fit. Treatment descriptions are provided in Table 1.

Year 10 stand volume was significantly affected by the FVM regimes $(p<0.001$, Table 4$)$ but was not influenced by stock type $(p=0.217)$ or the interaction of these two treatment levels $(p=0.965)$. 
Similar to height and DBH, year 10 stand volume in the FTO and FTT regimes was greater than the no-action control $(p<0.001)$. The FTT regime tended to have higher stand volumes than the FTO, however, this effect was marginal $(p=0.098)$. Stand volumes at year 10 averaged $9.3,18.8$, and $23.2 \mathrm{~m}^{3}$ $\mathrm{ha}^{-1}$ for the OOO, FTO, and FTT regimes, respectively. When comparing the individual treatment combinations, the S8 OOO and S15 OOO treatments had less stand volume than all stock types with the FTT regime ( 8.0 vs. $23.2 \mathrm{~m}^{3} \mathrm{ha}^{-1} ; p<0.031$ ). The $\mathrm{S} 60 \mathrm{OOO}$ treatment had $13.5 \mathrm{~m}^{3} \mathrm{ha}^{-1}$ less stand volume than the S60 FTT treatment $(p=0.020)$, but did not differ from the S8 FTT ( $p=0.221)$ or S15 FTT $(p=0.086)$ treatments. Stand volume $\left(\mathrm{m}^{3}\right.$ hectare $\left.{ }^{-1}\right)$ in year 10 was well-correlated with the cumulative shrub cover during the first and second growing seasons (Figure $7 ; p=0.016 ; R^{2}=0.60$ ). The resulting equation was:

$$
\text { Stand Volume (at age 10) }=6.572+40.368 \cdot \exp (-0.067 \cdot \text { Shrub Cover } \%)
$$

where Shrub Cover\% is the cumulative shrub cover of years 1 and 2.

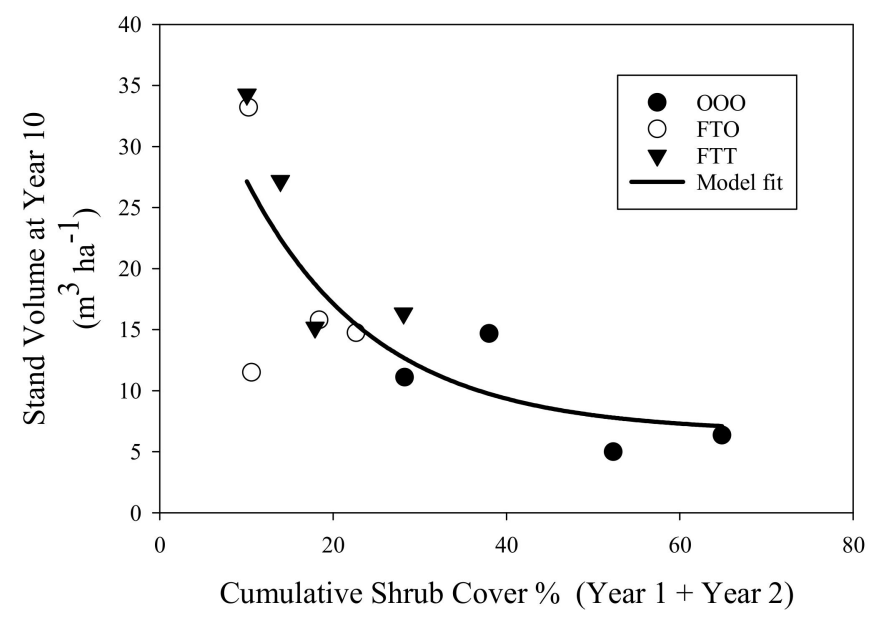

Figure 7. Relationship between cumulative shrub cover (\%) during the first and second year (year $1+$ year 2) and year 10 stand volume of Douglas-fir. Treatment descriptions are provided in Table 1.

\section{Discussion}

This study demonstrates that decisions made during the early years of stand establishment can have long-term consequences on the growth of Douglas-fir plantations. Decisions about forest vegetation management regime (FVM) and stock type selection significantly influenced tree size after ten growing seasons. The effect of FVM regime on tree size was more pronounced when compared to stock type and the interaction of these two treatment levels. This result suggests that all the stock types responded similarly to the FVM treatments in terms of seedling growth. There was, however, a significant FVM regime $x$ stock type interaction for seedling survival during the first four years of the study, indicating that the stock types tested had different levels of competition tolerance during the vulnerable time of establishment.

The positive effects of FVM on Douglas-fir seedling growth has been observed in several previous studies $[3,7,10-13]$. The higher survival and growth of plots treated with chemical vegetation control can be attributed to reduced competition with vegetation and associated increases in soil moisture during seedling establishment. The reduced vegetation cover in the FTO and FTT treatments increased soil moisture (expressed as ASW) during the dry summer season of the treatment year when compared to the no-action control. Increases in ASW associated with FVM have been shown to reduce drought stress and increase growth rate for newly planted Douglas-fir seedlings [7,8,22]. Results from this study extend these findings to a coarse-textured glacial soil type demonstrating the importance of preserving adequate soil moisture in the Mediterranean climate of the PNW through the use of judicious FVM regimes. 
Soil water availability also influences drought stress and hence survival as demonstrated by the significant FVM regime $x$ stock type interaction during the first four years of this study. It is proposed that the $\mathrm{S} 60$ seedlings growing in the $\mathrm{OOO}$ regime experienced elevated drought stress produced by the combined effects of intense competition for soil water and larger evaporative surface area, as leaf area has been shown to be well-correlated with water loss [23]. At the time of planting, the S60 stock type had a shoot volume that was four times that of the other stock types, potentially indicating an increased evaporative demand that the roots may not have been able to support. The strong relationship between seedling shoot volume and survival rate observed for the OOO regime (Figure 6) supports the conclusion that larger seedlings can be more vulnerable to mortality under moisture stress conditions. This relationship was not observed for the FTO or FTT regimes, indicating that maintaining less than $20 \%$ cover in the first year can be sufficient to reduce moisture stress and increase the survival of larger seedlings. In contrast to this, Wightman et al. (2018) [14] observed that S60 seedlings had higher mortality rates than S8 or S15 seedlings on two sites in the Oregon Coast Range treated with a fall site preparation combined with a spring release. The varying results of these studies may be due to site-specific conditions, the unique plant communities, higher water deficit in Oregon, or a combination of these factors. It is worth noting that the survival of seedlings in the S8 OOO and S15 OOO treatments decreased slowly throughout the study (especially during year 2) such that year 5 survival was only impacted by FVM regime.

In addition to effects on ASW, the FVM regimes applied in this study reduced vegetation cover through year 5 . Reductions in vegetation cover in response to FVM have been observed in several studies throughout the PNW [12,13,22], however the magnitude and duration of this reduction often varies from site to site. The persistent effect of FVM regime on vegetation cover in this study was governed by differences in the cover of shrubs, especially salal. This species is a vigorous native perennial evergreen shrub which competes strongly with regenerating conifer seedlings for soil water and, to a lesser extent, nutrients [24-27]. Salal can re-occupy a site following timber harvest through vegetative propagation utilizing the established root system of the parent plant. Price et al. (1986) [28] reported that removing the salal understory surrounding 32-year-old Douglas-fir trees on Vancouver Island increased soil water potential which produced increases in both tree photosynthetic rate and stomatal conductance.

The strong relationship between cumulative shrub cover during the first two growing seasons and stand volume in year 10 demonstrates the long-term influence of woody plant control. Using the presented equation for this relationship, increasing cumulative shrub cover during the first two growing seasons from $10 \%$ to $30 \%$ would reduce stand volume in year 10 by $79 \%\left(12.0 \mathrm{vs} 27.2 \mathrm{~m}^{3} \mathrm{ha}^{-1}\right)$.

Despite salal representing $74 \%$ of all shrub cover at the study site during the second growing season, none of the FVM regimes completely eradicated it from the landscape. By year 3, there were no differences in the average number of species per plot among the FVM regimes. In year 10, there were no longer differences among the FVM regimes in vegetation cover, even when analyzed by growth habit. These results indicate that the effects of FVM on the vegetation community tend to disappear over time. The recovery of vegetation abundance and diversity following FVM has also been observed by others [29-32]. Further analysis of region-wide datasets may permit plot-level species abundance to be expanded to the landscape scale.

Initial seedling size was not a significant covariate, indicating that morphologic differences in year 10 developed under field conditions rather than a product of nursery cultural regimes. The larger S60 stock type can outperform smaller seedlings when FVM regimes reduce early competition. These larger seedlings can, however, have reduced survivorship in the presence of increased plant competition. Larger stock types have also been reported to outperform smaller stock types for several conifer species including Douglas-fir in the PNW [16,17], Scots pine (Pinus sylvestris L.), and Norway spruce (Picea abies (L.) H. Karst.) in Sweden [33], and western white pine (Pinus monticola Douglas ex D. Don) in Idaho [34]. Conversely, there is evidence that tree size of different stock types can converge over time. Specific comparisons in this study (i.e, FTO regime across the stock types) as well as results 
presented by Wightman et al. (2018) [14] and Van der Driessche (1992) [15] demonstrate that it is possible for initial size differences to disappear at the planting site.

The largest stock type (S60) had strong field performance but may not be worth the financial investment. Logistical constraints from seedling storage, transportation, and the act of planting the largest stock type are imbedded in the costs presented in Table 5. To illustrate one aspect of these logistical constraints, S60 come packaged as 25 trees per bag whereas S8 seedlings come as 250 trees per box. Given the full suite of reforestation activities as well as their associated costs, forest managers will need to carefully consider the significant investment in the largest stock types (i.e., S60). It should be reiterated that the production of S60 Douglas-fir seedlings was experimental at the time this study was initiated and is not common for PNW nurseries. It is possible, however, that continued nursery development coupled with outside demand for larger stock types could decrease the cost of the S60 stock type.

Table 5. Establishment costs (in 2008 USD) per hectare for different combinations of stock type and forest vegetation management (FVM) regimes. Seedling and planting cots assume a planting density of 1074 tree ha ${ }^{-1}$. Planting crew and FVM costs were taken from Dinger and Rose 2009 [35].

\begin{tabular}{cccccc}
\hline Stock Type & FVM Regime & Seedlings & Planting Crew & FVM & Total Establishment Cost \\
\hline S8 & OOO & $\$ 269$ & $\$ 120$ & - & $\$ 389$ \\
S8 & FTO & $\$ 269$ & $\$ 120$ & $\$ 270$ & $\$ 659$ \\
S8 & FTT & $\$ 269$ & $\$ 120$ & $\$ 405$ & $\$ 794$ \\
S15 & OOO & $\$ 376$ & $\$ 120$ & - & $\$ 496$ \\
S15 & FTO & $\$ 376$ & $\$ 120$ & $\$ 270$ & $\$ 766$ \\
S15 & FTT & $\$ 376$ & $\$ 120$ & $\$ 405$ & $\$ 901$ \\
S60 & OOO & $\$ 1343$ & $\$ 140$ & - & $\$ 1483$ \\
S60 & FTO & $\$ 1343$ & $\$ 140$ & $\$ 270$ & $\$ 1753$ \\
S60 & FTT & $\$ 1343$ & $\$ 140$ & $\$ 405$ & $\$ 1888$ \\
\hline
\end{tabular}

\section{Conclusions}

The results of this study provide important insights into the interactions between FVM and seedling stock type. FVM increased ASW during the application year creating a more favorable growing environment for the newly planted seedlings during the region's Mediterranean summers. The FVM treatment applied in this study had a persistent effect on reducing vegetation cover early in the establishment phase. Competitive shrub cover during the first two growing seasons was well-correlated with stand volume in year 10, illustrating the importance of judicious vegetation control on sites with perennial shrub species, specifically salal. Increases in growth associated with FVM regime were found to be more pronounced than the effect of stock type.

Larger stock types, such as S60, have the potential to rapidly establish on a site when adequate vegetation control is applied, however, these larger seedlings were also more sensitive to competition during the early years of stand establishment. The smaller stock types tested (S8 and S15) were more tolerant to competition but were smaller than the largest stock type (S60) after 10 growing seasons. Under moderate levels of weed control, the survival of containerized stock types improves, but initial size differences disappeared over time calling into question the significant financial investment of the largest stock type tested.

Our results demonstrate that stock type selection and silvicultural prescriptions at the planting site have profound impacts on the long-term success of reforestation efforts. Forest managers must take into account information on site conditions (soil water holding capacity, climate, and vegetation community), seedling stock type performance, silvicultural treatment responses, and financial constraints when developing reforestation prescriptions. This study, along with future research across a range of site conditions and silvicultural treatments, represents the continual process of refining the Target Plant Concept. 
Author Contributions: Conceptualization, E.J.D.; Data curation, M.G.W. and E.J.D.; Formal analysis, M.G.W., C.A.G.-B. and E.J.D.; Investigation, E.J.D.; Writing—original draft, M.G.W.; Writing—review \& editing, C.A.G.-B., E.J.D., and M.G.W.

Funding: This research was supported by the Department of Forest Engineering, Resources, and Management and the Vegetation Management Research Cooperative at Oregon State University.

Acknowledgments: The members of the Vegetation Management Research Cooperative (VMRC) made this research possible. A special thanks goes to Olympic Resource Management for their enthusiastic support in the installation and maintenance of the study site. The patient guidance of the former VMRC Director, Robin Rose, was instrumental to the design, implementation, and long-term success of this project. We also extend a heartfelt thank you to the many students and research technicians who measured and maintained the study site.

Conflicts of Interest: The authors declare no conflicts of interest.

\section{References}

1. Fox, T.R.; Jokela, E.J.; Allen, H.L. The Development of Pine Plantation Silviculture in the Southern United States. J. For. 2007, 105, 337-347.

2. Vargas, F.; Rubilar, R.; Gonzalez-Benecke, C.A.; Sanchez-Olate, M.; Aracena, P. Long-term response to area of competition control in Eucalyptus globulus plantations. New For. 2018, 49, 383-398. [CrossRef]

3. Flamenco, H.N.; Gonzalez-Benecke, C.A.; Wightman, M.G. Long-term effects of vegetation management on biomass stock of four coniferous species in the Pacific Northwest United States. For. Ecol. Manag. 2019, 432, 276-285. [CrossRef]

4. Brancalion, P.H.S.; Campoe, O.; Mendes, J.C.T.; Noel, C.; Moreira, G.G.; van Melis, J.; Stape, J.L.; Guillemot, J. Intensive silviculture enhances biomass accumulation and tree diversity recovery in tropical forest restoration. Ecol. Appl. 2019, 29, e01847. [CrossRef] [PubMed]

5. Jokela, E.J.; Martin, T.A.; Vogel, J.G. Twenty-Five Years of Intensive Forest Management with Southern Pines: Important Lessons Learned. J. For. 2010, 108, 338-347.

6. Gonçalves, J.L.M.; Alvares, C.A.; Higa, A.R.; Silva, L.D.; Alfenas, A.C.; Stahl, J.; Ferraz, S.F.; Lima, W.; Brancalion, P.H.S.; Hubner, A.; et al. Integrating genetic and silvicultural strategies to minimize abiotic and biotic constraints in Brazilian eucalypt plantations. For. Ecol. Manag. 2013, 301, 6-27. [CrossRef]

7. Dinger, E.J.; Rose, R. Integration of soil moisture, xylem water potential, and fall-spring herbicide treatments to achieve the maximum growth response in newly planted Douglas-fir seedlings. Can. J. For. Res. 2009, 39, 1401-1414. [CrossRef]

8. Gonzalez-Benecke, C.A.; Dinger, E.J. Use of water stress integral to evaluate relationships between soil moisture, plant water stress and stand productivity in young Douglas-fir trees. New For. 2018, 49, 775-789. [CrossRef]

9. Balandier, P.; Collet, C.; Miller, J.H.; Reynolds, P.E.; Zedaker, S.M. Designing forest vegetation management strategies based on the mechanisms and dynamics of crop tree competition by neighboring vegetation. Forestry 2006, 79, 3-27. [CrossRef]

10. Dimock, E.J.; Beebe, T.F.; Collard, E.B. Planting-Site Preparation with Herbicides to Aid Conifer Reforestation. Weed Sci. 1983, 31, 215-221. [CrossRef]

11. Newton, M.; Preest, D.S. Growth and Water Relations of Douglas Fir (Pseudotsuga menziesii) Seedlings under Different Weed Control Regimes. Weed Sci. 1988, 36, 653-662. [CrossRef]

12. Rose, R.; Rosner, L.S.; Ketchum, J.S. Twelfth-year response of Douglas-fir to area of weed control and herbaceous versus woody weed control treatments. Can. J. For. Res. 2006, 36, 2464-2473. [CrossRef]

13. Maguire, D.A.; Mainwaring, D.B.; Rose, R.; Garber, S.M.; Dinger, E.J. Response of coastal Douglas-fir and competing vegetation to repeated and delayed weed control treatments during early plantation development. Can. J. For. Res. 2009, 39, 1208-1219. [CrossRef]

14. Wightman, M.G.; Gonzalez-Benecke, C.A.; Dinger, E.J. The Influence of Containerized Stock Type on the Growth and Survival of Douglas-fir Seedlings. Tree Plant. Notes 2018, 61, 134-141.

15. Van Driessche, R. Absolute and relative growth of Douglas-fir seedlings of different sizes. Tree Physiol. 1992, 10, 141-152. [CrossRef] [PubMed]

16. Rose, R.; Haase, D.L.; Kroiher, F.; Sabin, T. Root Volume and Growth of Ponderosa Pine and Douglas-Fir Seedlings: A Summary of Eight Growing Seasons. West. J. Appl. For. 1997, 12, 69-73. [CrossRef] 
17. Haase, D.L.; Rose, R.; Trobaugh, J. Field Performance of Three Stock Sizes of Douglas-fir Container Seedlings Grown with Slow-release Fertilizer in the Nursery Growing Medium. New For. 2006, 31, 1-24. [CrossRef]

18. Dumroese, K.R.; Landis, T.D.; Pinto, J.R.; Haase, D.L.; Wilkinson, K.W.; Davis, A.S. Meeting forest restoration challenges: Using the target plant concept. Reforesta 2016, 1, 37-52. [CrossRef]

19. Harrington, J.T.; Mexal, J.G.; Fisher, J.T. Volume Displacement Provides a Quick and Accurate Way to Quantify New Root Production. Tree Plant. Notes 1994, 45, 121-124.

20. Ritchie, J.T. Soil water availability. Plant Soil 1981, 58, 327-338. [CrossRef]

21. Littell, R.C.; Milliken, G.A.; Stroup, W.W.; Wolfinger, R.D. SAS System for Mixed Models; SAS Institute Inc.: Cary, NC, USA, 1996.

22. Dinger, E.J.; Rose, R. Initial fall-spring vegetation management regimes improve moisture conditions and maximize third-year Douglas-fir seedling growth in a Pacific Northwest plantation. N. Zeal. J. For. Sci. 2010, 40, 93-108.

23. Lambers, H.; Chapin, S.F.; Pons, L.P. Plant Physiological Ecology, 2nd ed.; Springer: New York, NY, USA, 2008; pp. 247-255.

24. Frasher, L.; Turkington, R.; Chanway, C.P. The biology of Canadian weeds. 102. Gaultheria shallon Pursh-PubAg. Can. J. Plant Sci. 1993, 73, 1233-1247. [CrossRef]

25. Mallik, A.U.; Prescott, C.E. Growth Inhibitory Effects of Salal on Western Hemlock and Western Red Cedar. Agron. J. 2001, 93, 85-92. [CrossRef]

26. Prescott, C.E.; Sajedi, T. The role of salal in forest regeneration problems in coastal British Columbia: Problem or symptom? For. Chron. 2008, 84, 29-36. [CrossRef]

27. Willoughby, I.H.; Forster, J.; Stokes, V.J. Gaultheria shallon can be controlled by the herbicides picloram, triclopyr or glyphosate if they are applied at the correct time of year. New For. 2018, 49, 757-774. [CrossRef]

28. Price, D.T.; Black, T.A.; Kelliher, F.M. Effects of salal understory removal on photosynthetic rate and stomatal conductance of young Douglas-fir trees. Can. J. For. Res. 1986, 16, 90-97. [CrossRef]

29. Boateng, J.O.; Haeussler, S.; Bedford, L. Boreal Plant Community Diversity 10 Years After Glyphosate Treatment. West. J. Appl. For. 2000, 15, 15-26. [CrossRef]

30. Lautenschlager, R.A.; Sullivan, T.P. Effects of herbicide treatments on biotic components in regenerating northern forests. For. Chron. 2002, 78, 695-731. [CrossRef]

31. Comeau, P.G.; Harper, G.J. Effects of vegetation control treatments for release of Engelmann spruce from a mixed-shrub community in southern British Columbia-Year 15 results. For. Chron. 2009, 85, 583-592. [CrossRef]

32. Comeau, P.G.; Fraser, E.C. Plant Community Diversity and Tree Growth Following Single and Repeated Glyphosate Herbicide Applications to a White Spruce Plantation. Forests 2018, 9, 107. [CrossRef]

33. Johansson, K.; Hajek, J.; Sjölin, O.; Normark, E. Early performance of Pinus sylvestris and Picea abies-A comparison between seedling size, species, and geographic location of the planting site. Scand. J. For. Res. 2015, 30, 388-400.

34. Regan, D.J.; Apostol, K.G.; Davis, A.S. Stocktype Influences Western White Pine Seedling Size 6 Years after Outplanting. Tree Plant. Notes 2015, 58, 37-41.

35. Dinger, E.J.; Rose, R. Combining Weed Control. Intensity and Seedling Stock Size to Maximize Douglas-Fir Productivity and Economic Return; VMRC 2008-2009 Annual Report; Oregon State University Publishing: Corvallis, OR, USA, 2009; pp. 22-29.

(C) 2019 by the authors. Licensee MDPI, Basel, Switzerland. This article is an open access article distributed under the terms and conditions of the Creative Commons Attribution (CC BY) license (http://creativecommons.org/licenses/by/4.0/). 